\title{
SEXUAL VIOLENCE AGAINST WOMEN IN ECUADOR: AN OVERVIEW FROM THE RURAL AND INDIGENOUS AREAS OF IMBABURA
}

DOI: $\underline{\text { http://doi.org/10.26758/11.1.1 }}$

\author{
Santiago BOIRA (1), Maria Teresa MUÑOZ (2), Anita NUDELMAN (3)
}

(1) University of Zaragoza, Faculty of Social Sciences and Labor, Spain; E-mail: mariateresammarco@hotmail.com

(2) Medicusmundi in Aragón, Spain; E-mail: anitanudelman@gmail.com

(3) Ben Gurion University, Faculty of Medical Sciences, Israel

Adress correspondence to: Santiago Boira, Facultad de Ciencias Sociales y del Trabajo, University of Zaragoza. C/Violante de Hungría, 23, 50009 Zaragoza, Spain. Ph.: +0034976761000; E-mail: sboira@unizar.es

\begin{abstract}
Objectives. Sexual violence against women is a major social problem for governments and institutions. International reports warn about its magnitude and its global nature and findings from Latin America have also confirmed the seriousness of the issue. The objective of this article is to address the problem of sexual violence against women in Ecuador, with emphasis on rural and indigenous areas.

Material and methods. The official data offered by the Attorney General of the State of Ecuador is analyzed. Likewise, the qualitative information provided by professionals in the province of Imbabura through interviews and focus groups.

Results. Quantitative data shows a very significant increase in the number of crimes of sexual violence against women in practically all the provinces of Ecuador in the past three years. Likewise, from a qualitative perspective, patriarchal culture is very present as one of the causes that explain violence. As for the manifestation of sexual violence, its most frequent form is within partner relationships. However, cases of incest, sexual abuse and aggression against minors within the family environment are also common.

Conclusions. Data for disaggregated and specific monitoring of sexual violence in Ecuador is limited. In this regard, the use of qualitative methodology to complement such information is recommended. This study identifies a serious situation both in terms of the prevalence and of the impact of sexual violence in Ecuador.
\end{abstract}

Keywords: sexual violence, Ecuador, abuse, rural areas, violence against women.

\section{Introduction}

The impact of sexual violence is a global issue which affects millions of girls and women (World Health Organization, 2013). The World Health Organization (WHO) defines sexual violence as "any sexual act, attempt to obtain a sexual act, unwanted sexual comments or advances, or acts to traffic, or otherwise directed, against a person's sexuality using coercion, by any person regardless of their relationship to the victim, in any setting, including but not limited to home and work" (WHO, 2002, p. 149). Likewise, it specifies different forms and contexts where sexual violence, which may include: "rape within marriage or dating relationships; rape by strangers; systematic rape during armed conflict; unwanted sexual advances or sexual harassment, including demanding sex in return for favours; sexual abuse of mentally or physically disabled people; sexual abuse of children; forced 
marriage or cohabitation, including the marriage of children; denial of the right to use contraception or to adopt other measures to protect against sexually transmitted diseases; forced abortion; violent acts against the sexual integrity of women, including female genital mutilation and obligatory inspections for virginity; forced prostitution and trafficking of people for the purpose of sexual exploitation" (WHO, 2002, p. 149-150).

Taking this into account, the Integral Organic Law for the Prevention and Eradication of Gender Violence against Women in Ecuador (2018), defines sexual violence as: "Any action that implies the violation or restriction of the right to sexual integrity and to voluntary decisions about their sexual and reproductive life, by means of threats, coercion, use of force or intimidation, including rape within marriage or other related kinship relationships - whether or not there is cohabitation - the intentional transmission of sexually transmitted infections (STIs), as well as forced prostitution, trafficking for the purpose of sexual exploitation, sexual harassment and other similar practices. Sexual violence also includes the involvement of children in sexual activities with an adult or any other person who is in a position of advantage over them, either because of their age, their greater physical or mental development, or because of a kinship, affective or trusting relationship, which binds them to the child, due to their position of authority or power. Sexual abuse, sexual exploitation and the use of the image of children and adolescents in pornography also constitute, among others, forms of sexual violence. Furthermore, this type of violence includes child pregnancy".

In Latin America, various studies have been conducted to try to establish the prevalence of the phenomenon in the region and have demonstrated the seriousness of the problem of gender and sexual violence (Contreras, Bott, Guedes, \& Dartnall, 2010; Bott, Guedes, Goodwin, \& Mendoza, 2012; WHO, 2013). Contreras et al. (2010) reviewed more than 200 published and unpublished documents on sexual violence in Latin America and the Caribbean concluding that sexual violence is a serious problem in the region and that it is most prevalent within a couple's relationship. Moreover, according to these authors, if sexual violence is caused by someone other than a partner, its most frequent forms are sexual abuse of children and youth, trafficking and sexual exploitation, sexual violence in the migration process, sexual harassment at work and sexual violence as a result of emergencies or armed conflict. The aforementioned study also shows that this type of violence has its origin in a social order based on gender inequality and power relations between men and women, where there is a tendency to legitimize violence against women in intimate relationships, to blame women, to justify men or to consider women as sexual objects.

In terms of the prevalence of the problem in Ecuador, the Demographic and Maternal and Child Health Survey (CEPAR, 2005) noted that $31 \%$ of Ecuadorian women of reproductive age reported that they had ever been physically, psychologically, or sexually abused. Similarly, the National Survey on Family Relations and Gender Violence against Women indicated that 6 out of every 10 women in Ecuador have experienced some type of gender violence. On the other hand, $25.70 \%$ have experienced some type of sexual violence and $14.5 \%$ have suffered sexual violence from their partner (National Institute of Statistics and Censuses of Ecuador, 2011; Camacho, 2014).

In Ecuador, this problem has been contextualized from different perspectives. For example, Friederic (2013) analyzes women's rights including their sexual and reproductive ones. Likewise, Goicolea (2001) and Goicolea, Wulff, Öhman and Sebastian (2009) explore issues such as women's needs or the risk of teenage pregnancy. Also, Boira, Tomas-Aragones and Rivera (2017) and Boira and Brunke (2018) examine the professional response and the context of impunity in which many of these crimes occur. Among the studies relevant to the context of this article are those which focus on the differences between the rural areas and the city (Astete \& García, 2012; Boira, Carbajosa, \& Méndez, 2015; Cuvi, Ferraro, \& Martínez, 2001), or on violence in relation to racial diversity in areas where mestizo, Ecuadorian and Afro-descendant communities live together (Prieto, Cuminao, Flores, Maldonado, \& Pequeño, 2005; Salgado, 2009). 
As Boira et al. (2015) point out, a markedly sexist and patriarchal culture persists in Ecuador, with a particular incidence in the rural areas where social pressure is strongest, thus increasing the vulnerability of women and making it difficult for them to speak out or to denounce.

This study was carried out in the province of Imbabura, located in the Andean region of Zone 1, in the north of Ecuador. It has an area of $4599 \mathrm{~km}^{2}$ and a population of 398,244. According to the last available census, the average age is 29 . In addition, $65.7 \%$ of its inhabitants are considered mestizo, 25.8\% indigenous and 5.4\% Afro-Ecuadorian, and the illiteracy rate is $10.6 \%$ (National Institute of Statistics and Censuses of Ecuador, 2010).

The objective of this article is to provide an overview of the issue of sexual violence against women in Ecuador, with an emphasis on rural and indigenous areas such as Imbabura. To this end, the data offered by the Ecuadorian Attorney General's Office will be examined together with relevant findings related to this type of violence, based on previous research carried out by the authors of this article.

\section{Material and methods}

For the purpose of this article, a mixed quantitative and qualitative strategy has been used. The following sections outline the central aspects of the analysis carried out in our study.

\section{Quantitative analysis}

In order to assess the data on the prevalence of sexual violence, a quantitative analysis of has been carried out concerning the different manifestations of sexual violence in each of Ecuador's provinces. The data was obtained from reports of the Ecuadorian Attorney General's Office (2018). For this work, we have analyzed the total sexual crimes reported by the Prosecutor's Office, as well as the categories of rape, sexual abuse and sexual harassment. One of the limitations of the data presented is that when violence against women or against a member of the family unit is discussed, not only women are included, and the motivations for such violence sometimes may be others than gender-based violence.

\section{Qualitative analysis}

The qualitative analysis is based on the first author's involvement in the field, as a Prometheus Researcher for the Ecuadorian Government during the years 2014 and 2015. As a result of his work in Ecuador, several publications were produced that addressed different aspects of gender violence in the country, mainly in the province of Imbabura: violence in rural areas (Boira et al., 2015), violence from the point of view of the professionals involved (Boira, et al., 2017), femicide (Boira \& Rivera, 2016), and impunity (Boira \& Brunke, 2018). In recent years, and as a result of different training processes carried out in the country, there is a growing concern about sexual violence towards women. This article uses primary materials from the articles cited above addressing the specific issue of sexual violence against women and girls. Specifically, it gathers the transcriptions of the interviews and focus groups carried out in Imbabura with professionals involved in addressing violence against women, both from the public and private spheres. From the set of research interviews, four are incorporated for this article, in which the participants were an activist from a women's organization, a social worker, a doctor from a judicial team and a judge. Regarding the focus groups, information is collected from four of them. Table 1 shows their main characteristics. 


\section{Table 1}

\section{Characteristics of the Focus Groups}

\begin{tabular}{llcccc}
\hline \multirow{2}{*}{ Group } & Site & $\begin{array}{c}\text { Number of } \\
\text { participants }\end{array}$ & Gender & $\begin{array}{c}\text { Mean age (in } \\
\text { years) }\end{array}$ & Ethnicity \\
\cline { 2 - 6 } 1 & $\begin{array}{l}\text { Peña } \\
\text { Herrera }\end{array}$ & 5 & 6 women & 42.4 & $\begin{array}{c}\text { Mestizo } \\
\text { Mestizo/indigen } \\
\text { ous/ of African } \\
\text { descent }\end{array}$ \\
3 & Ambuquí & 10 & $\begin{array}{c}2 \text { women } \\
8 \text { men }\end{array}$ & 36.4 & Mestizo \\
4 & $\begin{array}{l}\text { Peña } \\
\text { Herrera } \\
\text { García } \\
\text { Moreno }\end{array}$ & 10 & 6 men & 43.1 & Mestizo \\
\hline
\end{tabular}

\section{Results}

\section{Contextualization of crime and violence in Ecuador}

According to 2018 data, the most populated provinces of Ecuador are: first Guayas, with $25.07 \%$ of the national population, second Pichincha with $18.30 \%$ of the population and third Manabí, where a little more than $9.03 \%$ reside. These three provinces concentrate more than half of the country's population (52.4\%), which is why when we reviewed the number of crimes which amounted to 347,819 in 2018; these three provinces concentrated more than half of them (57\%): Guayas with $29 \%$, Pichincha with $21 \%$ and Manabí 7\%. In the case of the Province of Imbabura, 9,015 crimes were committed in 2018 , representing $8.8 \%$ of the crimes in the whole country. When examining the typologies of the major crimes, it was found that among the ten most prominent are two related to sexual violence: psychological violence against women or nuclear family members in third place with $13 \%$ and sexual abuse in the ninth place with 3\%. In the case of Imbabura, the crime of psychological violence against women or nuclear family members is the second most frequent, with 1,225 cases, and the category of rape, abuse, and sexual harassment is the fifth most frequent, with 515 crimes. It is significant that the most common typology is psychological violence and this type of violence tends to figure between the first and third places in all provinces. This fact leads us to reflect that the major type of violence in Ecuador is a violence that does not leave a physical mark on the victim, but certainly affects their self-esteem, reducing their ability to react, which indicates a clear relationship of inequality between the aggressor and the victim.

\section{Impact and prevalence of sexual violence}

When observing the data of cases of sexual violence against women in the country, it is noteworthy that of the total crimes for 2018 , almost $15 \%$ are about sexual violence $(51,900$ of a total of 347,819 ). The province where the greatest number of news items on crimes of sexual violence collected is Guayas with 19,032, which in this case represents $18.84 \%$ of the provincial total. If we analyze the percentage of sexual violence crimes in relation to the total crimes in each province, the provinces of Morona Santiago (30.38\%) and Manabí (26.70\%) have the highest percentage. In the case of Imbabura, the percentage is close to $20 \%$ and thus clearly above the average of Ecuador as a whole. Figure 1 shows the percentage of sexual violence crimes related to the total of crimes in the country. 


\section{Figure 1}

Percentage of crimes of sexual violence over total crimes

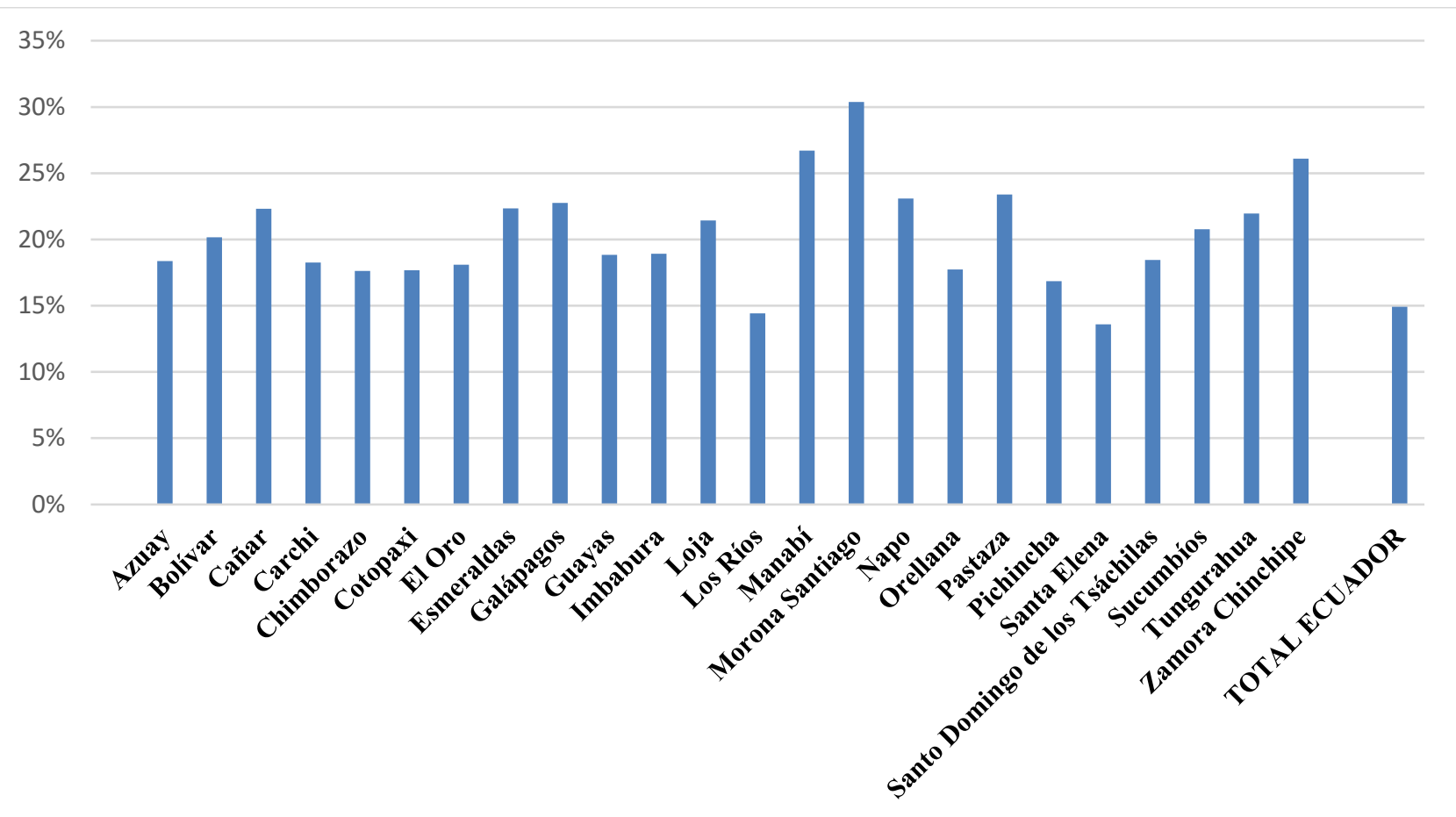

Source: developed base on data from the Public Prosecutor's Office

When relating to the different types of violence against women or members of the nuclear family, including physical, psychological, and sexual violence, it is clear that sexual violence is the most represented type of crimes, with Guayas having the highest percentage (30.68\%).

In reviewing the 2018 data on sexual harassment in Ecuador, it is necessary to bear in mind the differentiation between harassment of minors (18 years of age) and of adults. It is important to emphasize the fact that the breakdown of the data into harassment of minors and adults indicates that minors are being victims of this crime in a significant way. Out of a total of 2,401 sexual harassment crimes in 2018, Guayas and Pichincha again are the provinces with the highest number of victims of this crime. However, if analyzed according to the percentage of the population, the provinces with the greatest number of reports of crimes of harassment are Galapagos and Pastaza.

In the case of rape, Guayas and Pichincha are again the provinces where this crime mostly occurs. But it is important to look at the percentage of the population that these provinces represent and the percentage of this type of crimes in relation to it, in order to know exactly if the degree is higher.

In 2018, in the province of Imbabura, there were 227 sexual abuse crimes and 209 rape ones, which represent $2.5 \%$ and $3.5 \%$ of the crimes of this type that occur in the country.

As for sexual abuse against women, an increase over time of this crime can be observed and unfortunately more so over recent years, even doubling among some populations. This may be due to its being underreported before or perhaps because they were not aware that this was a crime, having "normalized" it, since women tend to suffer in silence, often without making the crime visible.

Table 2 illustrates the evolution of the crimes of sexual abuse and rape in Ecuador between the years 2016 and 2018, and shows a significant increase in practically all the provinces of the country in these two forms of crime. 


\section{Table 2}

Evolution of the crimes of sexual abuse and rape in Ecuador

\begin{tabular}{|c|c|c|c|c|c|c|}
\hline \multirow[b]{2}{*}{ Year/ province } & \multicolumn{3}{|c|}{ Sexual Abuse } & \multicolumn{3}{|c|}{ Rape } \\
\hline & 2016 & 2017 & 2018 & 2016 & 2017 & 2018 \\
\hline Azuay & 262 & 463 & 659 & 293 & 338 & 412 \\
\hline Bolívar & 11 & 46 & 53 & 49 & 84 & 62 \\
\hline Cañar & 81 & 88 & 128 & 84 & 114 & 124 \\
\hline Carchi & 27 & 57 & 67 & 47 & 49 & 36 \\
\hline Chimborazo & 114 & 145 & 144 & 136 & 165 & 205 \\
\hline Cotopaxi & 58 & 122 & 159 & 99 & 131 & 140 \\
\hline El Oro & 252 & 371 & 390 & 269 & 317 & 304 \\
\hline Esmeraldas & 135 & 211 & 286 & 210 & 212 & 224 \\
\hline Galápagos & 16 & 15 & 26 & 12 & 17 & 20 \\
\hline Guayas & 818 & 1320 & 2070 & 912 & 1014 & 1110 \\
\hline Imbabura & 127 & 212 & 227 & 132 & 175 & 209 \\
\hline Loja & 114 & 187 & 235 & 157 & 164 & 177 \\
\hline Los Ríos & 167 & 237 & 297 & 246 & 268 & 226 \\
\hline Manabí & 356 & 516 & 604 & 329 & 422 & 476 \\
\hline Morona Santiago & 82 & 156 & 239 & 198 & 229 & 234 \\
\hline Napo & 39 & 64 & 107 & 87 & 86 & 77 \\
\hline Orellana & 73 & 98 & 140 & 80 & 101 & 99 \\
\hline Pastaza & 42 & 46 & 117 & 51 & 47 & 87 \\
\hline Pichincha & 1028 & 1416 & 2101 & 879 & 938 & 921 \\
\hline Santa Elena & 59 & 126 & 145 & 79 & 88 & 109 \\
\hline $\begin{array}{l}\text { Santo Domingo de los } \\
\text { Tsáchilas }\end{array}$ & 139 & 295 & 278 & 195 & 241 & 225 \\
\hline Sucumbíos & 39 & 73 & 114 & 111 & 157 & 167 \\
\hline Tungurahua & 96 & 98 & 201 & 101 & 132 & 158 \\
\hline Zamora Chinchipe & 66 & 109 & 124 & 59 & 48 & 70 \\
\hline TOTAL FOR ECUADOR & 4201 & 6471 & 8911 & 4815 & 5538 & 5873 \\
\hline
\end{tabular}

Source: Author's compilation based on data provided by the Public Prosecutor's Office

Sexual violence in rural and indigenous areas of Imbabura

This section reviews some emerging issues related to sexual violence in the context of the above-mentioned research and, in particular, based on the focus groups carried out. Thus, it first addresses the role of patriarchal culture and traditional and modern values in explaining sexual violence. Secondly, the most common manifestations of sexual violence are characterized and finally, the consequences of violence for the victims, low reporting rates and impunity are analyzed. 


\section{Patriarchal culture, tradition and modernity}

In the descriptions made by informants, sexist attitudes and machismo frequently appear in the context of violence suffered by women. However, most of the time these attitudes and behaviors are only seen as affecting specific individuals, and not as a cultural manifestation that permeates institutions and constitutes a background structure which models interpersonal relationships at all levels of the social structure.

On the other hand, in addition to the transmission of patriarchal values, some narratives explain the violence that occurs in the communities as a result of issues such as poverty, overcrowding, or the influence of religious values related to sexual education. To illustrate, this is this how a teacher narrated his conversation with a young boy on the school bus:

"Just yesterday I was talking to a boy and he said, 'The girl over there is my girlfriend'; well, what is a girlfriend to you? "My girlfriend is my female", ah interesting, and what do you do with the female, ah I go out to take a chance [...] I see, my son: And what is a chance? This is "chancear" [making a gesture like having sexual relations]. I didn't know this. Well, who teaches you? Who teaches you this? My daddy... [...] Many times it is not that the father or the mother teaches him. Unfortunately the economic situation of the homes, they are poor and they share their room with the children [...] The father and the mother, like in a normal home, are going to have their intimacy, and they think that the children are already asleep; but the children are not asleep" (Ambuquí professionals Group).

Similarly, some informants see the problem of violence in relation to the loss of traditional values and in the confrontation between the new and the old, as well as in the double standards, which some call: "prudishness" in social relationships. This confrontation of the new and the old also incorporates other elements, such as the value of the indigenous perspective or the influence of the Catholic Church.

The cultural narratives of these traditions are very powerful and can make it difficult for women who suffer violence to get out of the situation and to report the aggression. In this regard, the role of professionals can be decisive:

"In the end, both for the priest and the psychologists the message is: stay [together], marriage is forever! If you won't go back to your husband, your child will have low grades, you can hurt yourself or want to kill yourself, [instead] you should make a healthy family environment. What does the woman do then, (she) endures" (Women's activist organization).

\section{Characterization of sexual violence}

This type of violence is significantly present in rural and indigenous areas. The types of sexual violence that appear in the informants' narratives are primarily sexual abuse and assault among adults both within and outside the couple, and sexual abuse of minors, especially girls. A type of harassment and abuse that occurs in the educational setting is also mentioned.

These situations tend to be hidden in the "public narrative" of community members because they are considered taboo. However, the professionals who work in these areas also refer to cases that allude to situations of incest and stepfather's relationships with their stepdaughters, who are girls or adolescents.

"Here in the parish I am the authority in charge. It is really a social problem that is difficult to deal with, not only here in the parish, and much more difficult in the rural areas where we live [...] Domestic violence is not only towards the wife but also towards the children, and it is not only 
physical violence and beating, there are also rapes from fathers to daughters. There are very serious cases that have really worried us a lot, and many girls have committed suicide here, according to investigations that have been carried out in cases in which were abused by parents, uncles, cousins..." (Group of Garcia Moreno professionals).

In another testimony, a professional from the judicial units comments:

"I have worked in rural communities, let's say with a mestizo population, an indigenous population, an Afro population... I don't have any data on that, but the abuse has been seen from grandparents to granddaughters, from fathers to daughters, from stepfathers to stepdaughters" (Social worker, judicial team).

In some of these narratives about sexual abuse the idea of "complicity" of some mothers in these situations is mentioned, in which even their social role as a mother begins to be performed by their daughter, leading to dramatic consequences that can result in suicide.

When relating to the sexual violence suffered by many women at the hands of their partners, a doctor from the judicial team comments:

"In that case that I was telling you about, you see, the couple has been drinking alcohol among friends and an argument erupts and they hit each other [...]. In the evening, he wants to have sex, and she is his wife, and because they have fought and she doesn't want to and she says, 'No, we're not going to fight, don't even look at me. And he takes her and forces her and has forced penetration and that is already a violation" (Medical judicial team).

Another form of abuse that appears in some narratives of different groups occurs from teachers against students in educational settings, mostly relationships between secondary school students (mainly girls) and teachers. These issues are well-known by the community, although, the same as regarding incest, they are covered up and do not initially emerge:

"The Rector has been told not to allow that [the relationship between students and teachers]. Here we have the example of a 15-year-old girl who got pregnant by a teacher, now they live together" (Group of Peña Herrera professionals).

This form of inter-generational abuse is reinforced in another one of the groups:

"Yes, exactly, for example, this is what it has been like here in the Educational Unit for many years, I remember since I was a student myself. There were relationships between teachers and students, many of them even made it to..., they didn't get married, the student and the teacher had their home and their family, and soon afterwards they [usually] separated as a result of their age gap, because imagine a graduate getting married: a 40-year-old man with a 16-year-old girl" (Group of Ambuquí professionals).

Consequences of violence for victims, lack of complaints, reporting and impunity

The consequences for girls and women who suffer this type of violence are always very serious often leading to psychological repercussions, low school performance, premature pregnancies, suicide and femicide. It is also necessary to consider that situations of sexual abuse usually continue over time and the consequences can be irreversible. One informant describes the following: 
"We have to sensitize the parents, and also students from the age of twelve or thirteen we should sensitize them so that they are they themselves are the spokespersons who warn or report, because [now] they remain silent out of fear so they never warn others [...] When we made a survey we realized by these students' performance, their low performance, they also seem to be distracted, and while the rest are playing games they suddenly leave" (Group of professionals García Moreno).

Regarding the influence of the experience of violence and sexuality on victims' body image, one of the professionals explains that women who suffer continuous sexual abuse feel that their body does not belong to them and may even feel it is alien to them.

"[When you talk to women] you shift from cultural issues to sexuality and even to the issue of intimacy. They say, for example, that they don't undress [to have sexual relations], so that their body doesn't belong to them. We wondered why they don't plan anything: first, because men don't allow them to take any contraceptives and because there is a taboo on the subject of ligatures, if a woman is going to have ligature it is because she is going to have another guy, they are going to be betrayed and all that. ... They don't make violence visible in their bodies" (Women's activist organization).

An issue that is often closely related to violence is early pregnancy among teenagers. There are many young girls who become mothers at a very early age and are left alone, as in most instances the father of their child disappears. Thus, in these cases, the bonding of the sons and daughters is usually with the mother and not with the father. It is also common for a single mother to bring her children into a new relationship. In other instances, these young mothers remain in relationships that can become violent at an early stage and the presence of the children may act as a deterrent to leaving the relationship, radically conditioning their way of life and hindering any type of decision.

The low rates of reporting and the impunity for many of these aggressions is another aspect that transpires from the narratives of the informants. The difficulty in reporting is due to different causes. On one hand, because it involves a complaint against family members, often questioning the credibility of the girl's testimony or even blaming her for what happened:

"I have seen cases of mothers who beat their daughters because they don't believe the daughters when they tell them that the father or stepfather is raping them" (Group of Garcia Moreno professionals).

On the other hand, another reason for not filing a complaint is that it is usually not going to succeed due to a lack of institutional support. However, it seems that professionals are well aware of cases of violence in the communities where they are working. One of them even asked himself: well, we are here, what can we do? Thus, expressing his tiredness and frustration:

"I know the problems of each of the homes, even if you don't believe it, one already knows what is happening here or what is happening there [...]. Here are all the authorities: what do we do? It's not just about telling the truth. Sometimes you feel powerless, as a teacher, because you don't have money and support of the other institutions, because in effect we are told: 'you have to do this, you have to fight against this, you have to finish this'. I always disagree with this, because these are nice words that they are telling us, and I ask, but how?" (Group of Ambuquí professionals).

Regarding the impunity in some of the narratives, the question of the 'role played by the indigenous justice system' appears. Although it is a right recognized in the Constitution, it is possible that it could have negative effects in addressing violence against women, provoking processes of revictimization or even protecting the aggressor, is noted. 
"The issue of indigenous justice is very sensitive because the national legal framework grants indigenous communities the power to apply their tradition and customs and to enforce justice [...]. I was about 10 years into my professional career there, and unfortunately I must say that in cases of domestic violence, people are re-victimized, especially women. I was in some meetings, especially those of the town councils where women were accused of these aggressions [...], those that are there are all men and they are older people y they tend to advise the woman:"don't do this because if you do it, he will punish you" or, "why did you do that? that's why he punished you", "and then comes the matter of keeping the family (together) despite everything" (Judge).

\section{Discussions}

The problem of the lack or inconsistency of statistical series showing the true impact of sexual violence is also an issue in other Latin American countries. Alméras and Calderón (2012) identify this situation, emphasizing that these countries do not have a system of indicators that can be standardized and compared over time. They also point out that the statistics do not show the real impact of the problem due to the low rate of complaints.

On the other hand, as already noted by the WHO (2002) the available data only reflect the cases reported, so it is to be expected that the severity of the problem may be much greater due to, as already noted in this article, the difficulty in reporting this type of violence. In line with the WHO report, sexual violence can be visualized as an iceberg floating in the water, where the small visible tip represents the cases reported to the police, but below the surface a significant unquantified part of the problem remains. In this regard, the use of qualitative methodology such as in-depth interviews with victims and, above all, the way in which information is obtained, are very important considerations when assessing the impact and depth of the phenomenon (Nudelman, Boira, Tsomaia, Balica, \& Tabagua, 2017).

In accordance with what has already been noted in the review by Contreras et al. (2010), the quantitative data available for Ecuador shows a very significant increase in the number of reports of crimes of sexual violence against women in practically all provinces in the last three years. The specific case of Imbabura province is no exception, as the data indicates that this type of crime has virtually doubled. For example, regarding sexual abuse, the number of crime reports has increased from 127 in 2016 to 227 in 2018. Likewise, the data on rape has risen from 132 in 2016, to 209 in 2018.

Patriarchal culture as a cause of violence is clearly evident in the findings of this study, thus supporting the conclusions of some of the most relevant authors who have studied this topic in the last decades at an international level (Dobash \& Dobash, 1979; Connell, 2013; Mshweshwe, 2020; Tonsing \&Tonsing, 2019). Patriarchal culture defines, in a very powerful way, the gender and sexual roles of what it means to be a man and a woman, their modes of behavior and social mandates, as well as what is and is not allowed for both men and women in emotional relationships and in sexual behavior. The loss of family and community values and the incorporation of individualism due to globalization and neoliberalism are also seen as the origin of dysfunctions within the family and of violence. However within this perspective, traditions can always mask a patriarchal vision that opts for permanence and asymmetry in gender relation.

The events of violence reported by the informants do not differ from those in other settings and the most common one is sexual violence in the context of partner relationships. However, cases of incest, as well as sexual abuse and aggression against minors in the family environment also stand out (Boira et al., 2015). Finally, the low rate of complaints and the ambivalent role of the so-called "indigenous justice" draw a scenario of impunity and reinforce the passivity and the silence of the victims. Regarding the low level of complaints, Bravo (2011) emphasizes that sometimes professionals themselves use arguments in defense of family stability that may deter reporting. He 
also underlines the lack of strong evidence and of objective witnesses, the slowness of the proceedings and the rigidity and complexity of criminal proceedings as additional causes of these situations.

Both the analysis of the reports of the Prosecutor's Office and the qualitative data from the field work indicate the seriousness of the prevalence of sexual violence as well as its impact on women, which are recognized as a political and social problem, affecting the Ecuadorian society. In this regard, the State has promoted different measures such as the recent legislation on gender violence (Integral Organic Law for the Eradication of Violence against Women, 2018); the creation of a specialty at the Public Prosecutor's Office on the issue of gender violence and the training and capacity building that some provinces are receiving on these issues. Nevertheless, the influence of the patriarchal culture on violence continues to be important in Ecuador, and therefore, it is crucial to increase the visibility of the sexual abuse experienced by women as well as the sex education they receive (Jerves et al., 2014).

Overall, in the Latin American region there have been important advances in national legislation in recent years. Nevertheless, there are still challenges to be faced in addressing violence prevention against women in all its forms. Likewise, as noted by the WHO (2006), it is necessary to continue fighting against the lack of impunity in which many of these crimes remain, shifting from words to actions and considering the crucial responsibility that States have in this matter.

Regarding the limitations of the study, the qualitative analysis is focused on a specific region, which makes it difficult to generalize the results to other areas of Ecuador. The objective of future research would be to expand the analysis to other areas of the country. In addition, it will be important to specifically analyze the roles played by the Catholic Church and by other cultural traditions in relation to sexual violence.

\section{Conclusions}

Even though different sources of information were used, our study has shown that there still is a lack of data on sexual violence in the Ecuadorian context and specifically of permanent and conveniently disaggregated series over time that would allow for specific monitoring of crimes of sexual violence against women. This is a fundamental factor, not only to assess the real impact of the problem, but also to promote and guide public policies.

In terms of the crimes of sexual abuse and rape in Ecuador, they have increased significantly in recent years both in Imbabura and in practically all the provinces of the country.

From a qualitative research point of view, and based on the discourses and narratives gathered in this study, patriarchal culture is very evident as one of the critical causes that explain violence. Regarding the characterization of sexual violence, the study concludes that among adults, women are sexually abused and assaulted both by their partner, as well as outside the couple relation, while minors, especially girls, are also sexually abused. Additional conclusions that can be drawn from the qualitative analysis are the low rate of reporting by victims and the impunity in which many of the perpetrators remain.

\section{References}

1. Alméras, D., \& Calderón, C. (Coords.) (2012). Si no se cuenta, no cuenta: Información sobre la violencia contra las mujeres. [If it is not told, it does not count: Information on violence against women]. Santiago de Chile: Naciones Unidas. Retrieved December 7, 2020 from https://repositorio.cepal.org/bitstream/handle/11362/27859/S2012012_es.pdf?sequence=1\&i sAllowed=y

2. Astete, S., \& García, A. (2012). Género, interculturalidad y sostenibilidad en la agenda de desarrollo de los pueblos originarios de Ecuador.[Gender, interculturality and sustainability 
in the development agenda of Ecuador's indigenous peoples]. Madrid: Departamento de Cooperación al Desarrollo. IEPALA. [Development Cooperation Department]. Retrieved December 7, 2020 from https://www.yumpu.com/es/document/read/38496423/gacnerointerculturalidad-y-sostenibilidad-en-la-agenda-de-iepala

3. Boira, S., \& Rivera, N. (2016). Estrellas en el cielo. Femicidio y violencia contra la mujer en el altiplano ecuatoriano [Stars in the sky. Femicide and violence against women in the Ecuadorian highlands]. Ibarra, Ecuador: Centauro Agencia Gráfica. Retrieved 5 June, 2020 from http://repositorio.utn.edu.ec/handle/123456789/6922

4. Boira, S., \& Brunke, L. I. (2018). Femicide, Judicial Proceedings and the Culture of Impunity in Ecuador. In: ACUNS, Femicide, State Accountability and Punishment (pp. 29-33), Vienna Liaison Office: ACUNS. Retrieved June 10, 2020 from https://acuns.org/wpcontent/uploads/2018/05/Femicide-Volume-IX.pdf

5. Boira, S., Tomas-Aragones, L., \& Rivera, N. (2017). Intimate Partner Violence and Femicide in Ecuador. Qualitative Sociology Review, 13, 30 - 47. Retrieved June 13, 2020 from http://qsr.webd.pl/ENG/Volume42/QSR_13_3.pdf

6. Boira, S., Carbajosa, P., \& Méndez, R. (2015). Miedo, conformidad y silencio. La violencia en las relaciones de pareja en áreas rurales de Ecuador. [Fear, conformity and silence. Violence in couple relationships in rural areas of Ecuador]. Psychosocial Intervention, 25(1), 9-17. doi: 10.1016/j.psi.2015.07.008.

7. Bott, S., Guedes, A., Goodwin, M., \& Adams, J. (2014). Análisis comparativo de datos poblacionales de 12 países. [Comparative analysis of population data from 12 countries]. Washington, DC: OPS. Retrieved December 4, 2020 from https://www.paho.org/hq/dmdocuments/2014/Violence1.24-WEB-25-febrero-2014.pdf

8. Bravo, E. (2011). Análisis y crítica de la Ley contra la Violencia a la mujer y la familia. Tesis previa a la obtención del Título de Abogado de los Tribunales de Justicia de la República y Licenciado en Ciencias Políticas y Sociales. Universidad de Cuenca. [Analysis and critic of the Law against Violence against women and the family. Thesis prior to obtaining the title of Lawyer of the Courts of Justice of the Republic and Degree in Political and Social Sciences. University of Cuenca]. Retrieved December 1, 2020 from http://dspace.ucuenca.edu.ec/bitstream/123456789/3373/1/TESIS.pdf

9. Camacho, G. (2014). La Violencia de Género contra las Mujeres en el Ecuador. Análisis de los resultados de la Encuesta Nacional sobre Relaciones Familiares y Violencia de Género contra las Mujeres. Quito: Consejo Nacional para la Igualdad de Género. [Gender violence against Women in Ecuador. Analysis of the results of the National Survey on Family Relations and gender violence against women. Quito: National Council for Gender Equality]. Retrieved December 1, 2020 from http://repositorio.dpe.gob.ec/bitstream/39000/2153/1/VCM-DPE009-2018.pdf

10. Connell, R. W. (2013). Gender and Power: Society, the Person and Sexual Politics. New York: John Wiley \& Sons.

11. Contreras, J. M., Bott, S., Guedes, A. \& y Dartnall, E. (2010). Violencia sexual en Latinoamérica y el Caribe: análisis de datos secundarios. Iniciativa de Investigación sobre la Violencia Sexual. [Sexual violence in Latin America and the Caribbean: analysis of secondary data. Sexual Violence Research Initiative]. Retrieved December 1, 2020 from https://www.paho.org/hq/dmdocuments/2010/Violencia_Sexual_LAyElCaribe.pdf

12. Cuvi, M., Ferraro, E., \& Martínez, A. (2001). Discursos sobre el género y ruralidad en el Ecuador. La década de 1990. [Discourses on gender and rurality in Ecuador. The decade of the 1990s]. Iconos, 11, 4-5. doi: 10.17141/iconos.11.2001.708.

13. Dobash, R.E., \& Dobash, D. (1979). Violence against wives - a case against the patriarchy. New York, NY: Free Press. 
14. Friederic, K. (2013). Violence against women and the contradictions of rights-in-practice in rural Ecuador. Latin American Perspectives, 41, 19-38. doi: 10.1177/0094582X13492140.

15. Goicolea, I. (2001). Exploring women's needs in an Amazon region of Ecuador. Reproductive Health Matters, 9, 193-202. doi: 10.1016/S0968-8080(01)90024-2.

16. Goicolea, I., Wulff, M., Öhman, A., \& Sebastian, M. S. (2009). Risk factors for pregnancy among adolescent girls in Ecuador's Amazon basin: A case-control study. Revista Panamericana de Salud Pública/Pan American Journal of Public Health, 26, 221-228. doi: 10.1590/S1020-49892009000900006.

17. Jerves, E., López, S., Castro, C., Ortiz, W., Palacios, M., Rober, P., \& Enzlin, P. (2014). Understanding parental views of adolescent sexuality and sex education in Ecuador: A qualitative study. Sex Education, 14(1), 14-27. doi: 10.1080/14681811.2013.814034.

18. Mshweshwe, L. (2020). Understanding domestic violence: masculinity, culture, traditions. Heliyon, 6(10). e05334. doi:https://doi.org/10.1016/j.heliyon.2020.e05334.

19. Nudelman, A., Boira, S., Tsomaia, T., Balica, E., \& Tabagua, S. (2017). Hearing Their Voices: Exploring Femicide among Migrants and Culture Minorities. Qualitative Sociology Review, 8(3), 48-70. Retrieved June 10, 2020 from http://qsr.webd.pl/ENG/Volume42/QSR_13_3.pdf

20. Prieto, M., Cuminao, C., Flores, A., Maldonado, G., \& Pequeño, A. (2005). Respeto, discriminación y violencia: mujeres indígenas en Ecuador, 1990-2004. [Respect, discrimination and violence: indigenous women in Ecuador, 1990-2004]. Quito: FLACSO. Retrieved June 10, 2020 from http://www.flacso.org.ec/docs/respeto.pdf

21. Salgado, J. (2009). Justicias y desprotección a mujeres indígenas contra la violencia. Posibilidades de interculturalidad. [Justice and lack of protection for indigenous women against violence. Possibilities of interculturality]. Aportes Andinos, 25, 61-72. Retrieved 30 June, 2020 from http://repositorio.uasb.edu.ec/bitstream/10644/1051/1/RAA-25-SalgadoViolencia\%20contra\%201as\%20mujeres\%20ind\%c3\%adgenas.pdf

22. Tonsing, J. C., \& Tonsing, K. N. (2019). Understanding the role of patriarchal ideology in intimate partner violence among South Asian women in Hong Kong. International Social Work, 62(1), 161-171. https://doi.org/10.1177/0020872817712566

23. ***CEPAR (2005). Informe Final de la Encuesta Demográfica y de Salud Materna e Infantil, Ecuador 2004. [Final Report of the Demographic and Maternal and Child Health Survey, Ecuador 2004]. (ENDEMAIN 2004). Ecuador: Centro de Estudios de Población y Desarrollo Social (CEPAR). Retrieved 5 December, 2020 from https://microdata.worldbank.org/index.php/catalog/979/related_materials

24. ***Ecuadorian Attorney General's Office (2018). Transparencia y rendición de cuentas. [Transparency and accountability]. Retrieved June 1, 2020 from https://www.fiscalia.gob.ec/rendicion-de-cuentas/

25. ***Integral Organic Law for the Prevention and Eradication of Gender Violence against Women in Ecuador (2018). Official Registry No 175- Monday, February 5, 2018 Supplement. National Assembly of the Republic of Ecuador. Retrieved December 5, 2020 from https://www.igualdad.gob.ec/wpcontent/uploads/downloads/2018/05/ley_prevenir_y_erradicar_violencia_mujeres.pdf

26. ***National Institute of Statistics and Censuses of Ecuador (2010). Censo de Población y Vivienda [Population and Housing Census]. Retrieved December 6, 2020 from http://www.ecuadorencifras.gob.ec/censo-de-poblacion-y-vivienda/.

27. ***National Institute of Statistics and Censuses of Ecuador (2011). Encuesta Nacional de Relaciones Familiares y Violencia de Género contra las Mujeres de 2011. Quito: Gobierno de Ecuador. [National Survey on family relations and gender violence against women. Quito: Government of Ecuador]. Retrieved December 15, 2019 from https://www.ecuadorencifras.gob.ec/estadisticas/ 
28. ***World Health Organization (2002). World report on violence and health, Geneva: WHO. $\begin{array}{llll}\text { Retrieved November } & 4, & 2020 & \text { from }\end{array}$ https://apps.who.int/iris/bitstream/handle/10665/42512/9241545623_eng.pdf?sequence=1\&i sAllowed $=\mathrm{y}$

29. *** World Health Organization (2006). Ending violence against women. From words to action. New York: United Nations. Retrieved November 4, 2020 from https://www.unwomen.org//media/headquarters/media/publications/un/en/englishstudy.pdf?la=en \&vs=954

30. ***World Health Organization (2013). Global and Regional Estimates of Violence Against Women: Prevalence and Health Effects of Intimate Partner Violence and Non-Partner Sexual Violence. Geneva: World Health Organization. Retrieved December 1, 2020 from https://apps.who.int/iris/bitstream/handle/10665/85239/9789241564625_eng.pdf?sequence= $1 \&$ isAllowed=y 